Proc. Indian Acad. Sci. (Earth Planet. Sci.), Vol. 93, No. 1, March 1984, pp. 27-36.

(C) Printed in India.

\title{
On the occurrences of dry and wet sequences in the Brahmaputra valley
}

\author{
S KALITA and S K SARMAH \\ Department of Environmental Science, Gauhati University, Gauhati 781 014, India
}

MS received 21 May 1983; revised 15 October 1983

\begin{abstract}
Occurrence of dry and wet days in the Brahmaputra Valley has been studied using a first-order Markov Chain model. The model is fitted to the daily rainfall series recorded at ten stations widely distributed in the valley. The adequacy of the model is tested and found suitable. At all the stations, dry and wet spells having different durations follow geometric distribution. For pre-monsoon and monsoon seasons, the expected dry and wet days, the expected length of a weather cycle and the return period of dry spells having different durations are calculated, and the results for different stations are compared.
\end{abstract}

Keywords. Markov chain; dry spell; wet spell; weather cycle; return period; Brahmaputra valley.

\section{Introduction}

It is evident that the occurrences of dry and wet days depend on the conditions of the preceding days, that is, daily rainfall tends to persist. The degree of persistency and hence the distribution of dry and wet days are different for different rainfall zones. As the Brahmaputra Valley is surrounded by high mountain ranges, its rainfall is greatly influenced by its topography. Hence, the distribution of dry and wet days at different locations in the valley must be different. Medhi (1976) studied the dry and wet days at Gauhati, an inland station in the Brahmaputra Valley and found that the first-order Markov Chain model gives better fit to the data than the higher order models. The model was first applied in the rainfall climatology by Gabriel and Neumann (1962). Subsequently, several workers applied and verified the applicability of the model at different places (Caskey 1963; Weiss 1964; Feyerherm and Bark 1967; Fitzpatrick and Krishnan 1967; Watterson and Legg 1967; Sundararaj and Ramachandra 1975; Bhargava et al. 1977; Victor and Sastry 1979). In this paper, the occurrences of dry and wet days have been studied by applying the first-order Markov Chain model at ten stations widely distributed in the Brahmaputra Valley and the results are compared.

\section{The model}

Considering the rainfall occurrence, a day may be categorised by only two possible outcomes - either dry or wet. Now, assuming that the weather condition of a particular day depends only on the weather condition of the just preceding day and representing the dry and wet days by the states ' 0 ' and ' 1 ' respectively, the daily rainfall series may be represented by an irreducible first-order binary Markov-Chain with two ergodic states ' 0 ' and ' 1 '. Such a chain is described by the initial state and by a set of transition 
probability matrices,

$$
\begin{aligned}
A^{n} & =\left[\begin{array}{cc}
1-P_{0} & P_{0} \\
P_{1} & 1-P_{1}
\end{array}\right]^{n}, n=1,2,3, \ldots \\
& =\frac{1}{P_{0}+P_{1}}\left(\begin{array}{ll}
P_{1} & P_{0} \\
P_{1} & P_{0}
\end{array}\right)+\frac{\left(1-P_{0}-P_{1}\right)^{n}}{P_{0}+P_{1}}\left(\begin{array}{rr}
P_{0} & -P_{0} \\
-P_{1} & P_{1}
\end{array}\right)
\end{aligned}
$$

where $\boldsymbol{P}_{0}=$ conditional probability of a wet day following a dry day and $P_{1}=$ conditional probability of a dry day following a wet day. If $a=$ frequency of wet days following a dry day, $b=$ frequency of dry days following a wet day, $N_{1}=$ total number of dry days, and $N_{2}=$ total number of wet days then,

and

$$
\left.\begin{array}{l}
P_{0}=P_{r}(W \mid D)=a / N_{1} \\
P_{1}=P_{r}(D \mid W)=b / N_{2}
\end{array}\right\}
$$

If in (1) $n \rightarrow \infty$ and the chain is homogeneous, the chain will be in a steady state and the transition probability will be independent of the step of transition $n$. Thus,

$$
\lim _{n \rightarrow \infty} A^{n}=\left(\begin{array}{ll}
\pi_{0} & \pi_{1} \\
\pi_{0} & \pi_{1}
\end{array}\right)
$$

where, $\quad \pi_{0}=P_{1} /\left(P_{0}+P_{1}\right)$ and $\pi_{1}=P_{0} /\left(P_{0}+P_{1}\right)$.

$\pi_{0}$ and $\pi_{1}$ are called the model parameters corresponding to dry and wet days respectively.

From the central limit theorem for dependent variables, the distribution of the number of dry and wet days in a sequence of $n$ transitions for large $n(n \rightarrow \infty)$, is asymptotically normal with mean,

$$
E_{d}=N \pi_{0}=N P_{1} /\left(P_{0}+P_{1}\right) \text { and } E_{w}=N \pi_{1}=N P_{0} /\left(P_{0}+P_{1}\right)
$$

for dry and wet days respectively, and variance,

$$
\operatorname{Var}(E)=N P_{0} P_{1}\left(2-P_{0}-P_{1}\right) /\left(P_{0}+P_{1}\right)^{3},
$$

where $N\left(=N_{1}+N_{2}\right)$ is the total number of sequences in the series.

Now, the probability of dry and wet spells having length of run, $i$ may be represented by the geometric distribution models,

and

$$
\left.\begin{array}{l}
P_{r}(\text { dry })=P_{0}\left(1-P_{0}\right)^{i-1} \\
P_{r}(\text { wet })=P_{1}\left(1-P_{1}\right)^{i-1}, i=1,2,3, \ldots
\end{array}\right\}
$$

Their cumulative probability will be,

and

$$
\left.\begin{array}{l}
f_{s d}=\sum_{j=1}^{i} P_{0}\left(1-P_{0}\right)^{j-1}=1-\left(1-P_{0}\right)^{i} \\
f_{s w}=\sum_{j=1}^{i} P_{1}\left(1-P_{1}\right)^{j-1}=1-\left(1-P_{1}\right)^{i}
\end{array}\right\}
$$

respectively, where $i=$ length of run of the spell of highest duration.

The expected average lengths of dry and wet spells, and hence the expected length of a weather cycle is given by,

$$
E(C)=E(D)+E(W)=\left(1 / P_{0}\right)+\left(1 / P_{1}\right)=\left(P_{0}+P_{1}\right) / P_{0} P_{1},
$$


where $E(D)=1 / P_{0}=$ expected average length of dry spells and $E(W)=1 / P_{\text {, }}$ $=$ expected average length of wet spells.

\section{Data and analysis}

The daily rainfall data recorded at ten widely distributed stations in the Brahmaputra Valley for the period, 1976-1979 are used in this study. The particulars of the stations are given in table 1 .

On the basis of rainfall climatology, there are three seasons in Indian climate: (i) premonsoon, (ii) monsoon and (iii) post-monsoon. The series of daily rainfall data for each station are therefore broken up into three series according to these seasons. Thus, four series are obtained for each station including the annual data series.

The period March to May having a length of 92 days constitutes the pre-monsoon season. The monsoon and the post-monsoon seasons include the months June to September (122 days) and October to February (151 days and 152 days for a leap-year) respectively. Thus for the period 1976-1979, the total length of the pre-monsoon, monsoon, post-monsoon and annual data series of daily rainfall for each station will be $368,488,605$ and 1461 days respectively.

In this study, a day is considered to be dry if the amount of rainfall within that day is less than $1 \mathrm{~mm}$ or nil; otherwise it is considered as a wet day. This criterion of dry and wet days is the same for all the series and for all the stations. The frequencies of the pairs of consecutive days with weather condition dry followed by dry, dry followed by wet, wet followed by dry and wet followed by wet are counted out for each series. From these conditional frequencies, by using equation (2), the conditional probabilities $P_{0}$ and $P_{1}$, and hence other parameters can be calculated.

\section{Results and discussions}

\subsection{Adequacy of the model}

Statistical tests suggested by Anderson and Goodman (1957) are used to examine the adequacy of the model. $\chi^{2}$-value of the test of independence for the first-order Markov

Table 1. Particulars of the selected stations.

\begin{tabular}{lccc}
\hline Station & $\begin{array}{c}\text { Latitude } \\
(\mathbf{N})\end{array}$ & $\begin{array}{c}\text { Longitude } \\
\text { (E) }\end{array}$ & $\begin{array}{c}\text { Height from MSL } \\
\text { (meter) }\end{array}$ \\
\hline Dhubri & $26^{\circ}-01^{\prime}$ & $89^{\circ}-59^{\prime}$ & 35 \\
Gauhati & $26^{\circ}-05^{\prime}$ & $91^{\circ}-43^{\prime}$ & 54 \\
Tangla & $26^{\circ}-39^{\prime}$ & $91^{\circ}-55^{\prime}$ & 78 \\
Tezpur & $26^{\circ}-37^{\prime}$ & $92^{\circ}-47^{\prime}$ & 79 \\
Majbat & $26^{\circ}-45^{\prime}$ & $92^{\circ}-21^{\prime}$ & - \\
Lumding & $25^{\circ}-45^{\prime}$ & $93^{\circ}-11^{\prime}$ & 149 \\
Chaparmukh & $26^{\circ}-12^{\prime}$ & $92^{\circ}-31^{\prime}$ & 66 \\
Haflong & $25^{\circ}-10^{\prime}$ & $93^{\circ}-01^{\prime}$ & 682 \\
North-Lakhimpur & $27^{\circ}-14^{\prime}$ & $94^{\circ}-07^{\prime}$ & 102 \\
Dibrugarh & $27^{\circ}-28^{\prime}$ & $94^{\circ}-55^{\prime}$ & 106 \\
\hline
\end{tabular}


Chain model is calculated for each series and the results are compared. However, higher order models beyond one are not tried.

Under null hypothesis, the $\chi^{2}$-values with 1 degree of freedom (d.f.) of the test of independence for a first-order Markov Chain model for all the series are presented in table $2 \mathrm{a}$. It is observed that all the $\chi^{2}$-values are significant above $2 \%$ level $(P<0.02)$ except the monsoon season at Lumding. Hence, the null hypothesis may be rejected against its alternative hypothesis that the successive sequences of dry and wet days are dependent.

The relative adequacy of the model for different series at different stations may also be investigated from table $2 \mathrm{a}$. It is evident that as the $\chi^{2}$-values increase, its level of significance decreases (null hypothesis becomes significant). Again, for the significant $\chi^{2}$-values, the null hypothesis may be rejected against its alternative hypothesis that the successive sequences of dry and wet days are dependent. Hence the larger values of $\chi^{2}$ show a better fit of the model. A comparison of the $\chi^{2}$-values therefore represents the relative adequacy of the model for different periods at different stations.

The relatively better and worse fit of the model for different periods is summarised in table $2 \mathrm{~b}$. For both pre-monsoon and monsoon periods $\chi^{2}$-values are maximum at Gauhati and minimum at Lumding. This indicates the best fit of the model at Gauhati and relatively worse fit at Lumding for pre-monsoon and monsoon periods. During post-monsoon period daily rainfall follows the model most accurately at Majbat and least accurately at Lumding. The combined data series of the said three periods (i.e., the annual series) show best fit of the model at Dibrugarh and worst fit at Dhubri.

Table 2a. $\chi^{2}$-values for the test of adequacy of first-order Markov Chain model with 1 degree of freedom (d.f.).

\begin{tabular}{lcccc}
\hline Station & Pre-monsoon & Monsoon & Post-monsoon & Annual \\
\hline Dhubri & 28.9 & 23.0 & 34.4 & 17.2 \\
Gauhati & 88.6 & 67.3 & 105.9 & 50.7 \\
Tangla & 8.6 & 9.9 & 49.9 & 107.6 \\
Tezpur & 57.2 & $24 \cdot 1$ & 61.8 & 243.1 \\
Majbat & 38.8 & 10.0 & 109.8 & 191.5 \\
Lumding & 8.5 & 2.4 & 5.9 & 51.1 \\
Chaparmukh & 67.6 & 20.7 & 24.3 & 186.7 \\
Haflong & 24.0 & 8.6 & 82.5 & 125.1 \\
North-Lakhimpur & 32.3 & 43.9 & 64.6 & 227.1 \\
Dibrugarh & 23.2 & 56.0 & 100.5 & 275.4 \\
\hline
\end{tabular}

Table 2b. Relatively better and worse fit of first-order Markov Chain model for different periods.

\begin{tabular}{lcc}
\hline Period & Relatively better fit at & Relatively worse fit at \\
\hline Pre-monsoon & Gauhati & Lumding \\
Monsoon & Gauhati & Lumding \\
Post-monsoon & Majbat & Lumding \\
Annual & Dibrugarh & Dhubri \\
\hline
\end{tabular}




\subsection{Dry and wet days}

The expected numbers of dry and wet days with their standard deviations calculated using equations $4(\mathrm{a})$ and $4(\mathrm{~b})$ are presented in table 3 . It seems that the observed and the expected numbers of dry and wet days are nearly equal. This indicates that the model parameters, $\pi_{0}$ and $\pi_{1}$ are approximately equal to the simple probabilities of dry $\left(P_{d}\right)$ and wet $\left(P_{w}\right)$ days respectively.

\subsection{Dry and wet spells}

For each station, the expected frequencies of dry and wet spells having different durations or lengths of run for the pre-monsoon and monsoon periods are calculated using equation (5). Post-monsoon period is omitted as it contains very few rainy days. To test the goodness of fit of the geometric distribution model, $\chi^{2}$-test is applied.

Table 3. Observed and expected number of dry and wet days for all the stations.

\begin{tabular}{|c|c|c|c|c|c|c|c|c|}
\hline \multirow[b]{2}{*}{ Station } & \multicolumn{2}{|c|}{ Pre-monsoon } & \multicolumn{2}{|c|}{ Monsoon } & \multicolumn{2}{|c|}{ Post-monsoon } & \multicolumn{2}{|c|}{ Annual } \\
\hline & O & $\mathbf{E}$ & 0 & $\mathrm{E}$ & $\mathrm{O}$ & $\mathbf{E}$ & O & $\mathbf{E}$ \\
\hline Dhubri & 273 & 273 & 236 & 236 & 548 & 548 & 1057 & 1083 \\
\hline Gauhati & 219 & 218 & 172 & 172 & 524 & 528 & 915 & 916 \\
\hline Tangla & 285 & 285 & 274 & 274 & 542 & 542 & 1101 & 1101 \\
\hline Tezpur & 242 & 241 & 228 & 228 & 539 & 539 & 1009 & 1007 \\
\hline Majbat & 248 & 248 & 250 & 250 & 546 & 547 & 1044 & 1044 \\
\hline Lumding & 260 & 260 & 287 & 287 & 543 & 543 & 1090 & 1090 \\
\hline Chaparmukh & 264 & 263 & 286 & 286 & 556 & 556 & 1106 & 1106 \\
\hline Haflong & 259 & 258 & 284 & 284 & 557 & 557 & 1100 & 1100 \\
\hline North-Lakhimpur & 209 & 209 & 168 & 168 & 481 & 481 & 858 & 857 \\
\hline Dibrugarh & 204 & 203 & 177 & 178 & 485 & 485 & 866 & 865 \\
\hline \multirow[t]{3}{*}{ Mean } & 246 & 246 & 236 & 236 & 532 & 533 & 1014 & 1017 \\
\hline & \multicolumn{2}{|c|}{ Pre-monsoon } & \multicolumn{2}{|c|}{ Monsoon } & \multicolumn{2}{|c|}{ Post-monsoon } & \multicolumn{2}{|c|}{ Annual } \\
\hline & $\mathrm{O}$ & $\mathrm{E}$ & $\mathrm{O}$ & $\mathbf{E}$ & $\mathrm{O}$ & $\mathbf{E}$ & $\mathbf{O}$ & $\mathbf{E}$ \\
\hline Dhubri & 95 & 95 & 252 & 252 & 57 & 57 & 404 & 378 \\
\hline Gauhati & 149 & 150 & 316 & 316 & 81 & 77 & 546 & 546 \\
\hline Tangla & 83 & 83 & 214 & 214 & 63 & 63 & 360 & 360 \\
\hline Tezpur & 126 & 127 & 260 & 260 & 66 & 66 & 452 & 454 \\
\hline Majbat & 120 & 120 & 238 & 238 & 59 & 58 & 417 & 417 \\
\hline Lumding & 108 & 108 & 201 & 201 & 62 & 62 & 371 & 371 \\
\hline Chaparmukh & 104 & 105 & 202 & 202 & 49 & 49 & 355 & 356 \\
\hline Haflong & 109 & 110 & 204 & 204 & 48 & 48 & 361 & 362 \\
\hline North-Lakhimpur & 159 & 159 & 320 & 320 & 124 & 124 & 603 & 604 \\
\hline Dibrugarh & 164 & 165 & 311 & 310 & 120 & 120 & 595 & 596 \\
\hline Mean & 122 & 122 & 252 & 252 & 73 & 72 & 447 & 444 \\
\hline
\end{tabular}

N. B : $O=$ Observed number of days; $E=$ Expected number of days. 
Table 4a. Expected and observed frequencies of dry and wet spells for pre-monsoon and monsoon periods observed at the station Tezpur and the corresponding $\chi^{2}$-values.

\begin{tabular}{|c|c|c|c|c|c|c|c|c|}
\hline \multirow{4}{*}{$\begin{array}{l}\text { Run length } \\
\text { (in days) }\end{array}$} & \multicolumn{8}{|c|}{ Frequencies of spells } \\
\hline & \multicolumn{4}{|c|}{ Pre-monsoon } & \multicolumn{4}{|c|}{ Monsoon } \\
\hline & \multicolumn{2}{|c|}{ Dry } & \multicolumn{2}{|c|}{ Wet } & \multicolumn{2}{|c|}{ Dry } & \multicolumn{2}{|c|}{ Wet } \\
\hline & 0 & $\mathbf{E}$ & 0 & $\mathrm{E}$ & 0 & $\mathrm{E}$ & 0 & $\mathbf{E}$ \\
\hline 1 & 13 & $11 \cdot 1$ & 23 & $20-2$ & 42 & $39 \cdot 4$ & 38 & $35 \cdot 2$ \\
\hline 2 & 11 & 8.8 & 9 & $12 \cdot 2$ & 28 & $23 \cdot 1$ & 23 & $22 \cdot 4$ \\
\hline 3 & 6 & 6.9 & 8 & $7 \cdot 4$ & 9 & $13 \cdot 5$ & 14 & $14 \cdot 3$ \\
\hline 4 & 3 & $5 \cdot 5$ & 4 & 4.5 & 2 & 7.9 & 4 & $9 \cdot 1$ \\
\hline 5 & 6 & $4 \cdot 3$ & 2 & $2 \cdot 7$ & 5 & $4 \cdot 6$ & 9 & 5.8 \\
\hline 6 & 2 & 3.4 & 3 & 1.6 & 2 & $2 \cdot 7$ & 3 & 3.7 \\
\hline 7 & 2 & $2 \cdot 7$ & 1 & 1.0 & 2 & 1.6 & 3 & $2 \cdot 4$ \\
\hline 8 & 2 & $2 \cdot 2$ & 0 & $0-6$ & 3 & 0.9 & 1 & 1.5 \\
\hline 9 & 1 & 1.7 & 0 & 0.4 & 0 & 0.5 & 1 & 1.0 \\
\hline 10 & 2 & $1 \cdot 3$ & 1 & 0.2 & 2 & $0-3$ & 0 & $0-6$ \\
\hline$>10$ & 5 & 5.0 & 0 & $0 \cdot 3$ & 0 & 0.4 & 1 & $1 \cdot 1$ \\
\hline$x^{2}$ & \multicolumn{2}{|c|}{$2 \cdot 15$} & \multicolumn{2}{|c|}{1.28} & \multicolumn{2}{|c|}{$7.94^{*}$} & \multicolumn{2}{|c|}{5.03} \\
\hline d.f. & \multicolumn{2}{|c|}{3} & \multicolumn{2}{|c|}{2} & \multicolumn{2}{|c|}{3} & \multicolumn{2}{|c|}{4} \\
\hline
\end{tabular}

N. B.: $O=$ Observed; $E=$ Expected; d.f. $=$ degrees of freedom; ${ }^{*}=$ Significant at $5 \%$ level.

Table 4b. $\chi^{2}$-values for the test of goodness of fit of the geometric distribution model to the frequency distributions of dry and wet spells.

\begin{tabular}{|c|c|c|c|c|c|c|c|c|}
\hline \multirow[b]{3}{*}{ Station } & \multicolumn{4}{|c|}{ Pre-monsoon } & \multicolumn{4}{|c|}{ Monsoon } \\
\hline & \multicolumn{2}{|c|}{ Dry } & \multicolumn{2}{|c|}{ Wet } & \multicolumn{2}{|c|}{ Dry } & \multicolumn{2}{|c|}{ Wet } \\
\hline & & d.f. & & d.f. & & d.f. & & d.f. \\
\hline Dhubri & $8.99^{*}$ & 3 & 0.76 & 2 & $3 \cdot 84$ & 3 & $5 \cdot 21$ & 4 \\
\hline Gauhati & $9 \cdot 61$ & 5 & $9 \cdot 44$ & 4 & $2 \cdot 38$ & 4 & $14 \cdot 60^{*}$ & 6 \\
\hline Tangla & 6.94 & 3 & $1 \cdot 21$ & 1 & $7 \cdot 26$ & 4 & 2.59 & 3 \\
\hline Tezpur & $2 \cdot 15$ & 3 & $1 \cdot 28$ & 2 & $7 \cdot 94^{*}$ & 3 & $5 \cdot 03$ & 4 \\
\hline Majbat & $12 \cdot 42^{* *}$ & 3 & 0.80 & 2 & $10 \cdot 68^{*}$ & 4 & $2 \cdot 93$ & 3 \\
\hline Lumding & $5 \cdot 59$ & 4 & 1.68 & 2 & $7 \cdot 72$ & 4 & 0.64 & 3 \\
\hline Chaparmukh & $9 \cdot 40^{* *}$ & 2 & 0.78 & 2 & 8.00 & 4 & $7 \cdot 64$ & 3 \\
\hline Haflong & $3 \cdot 71$ & 2 & $1 \cdot 20$ & 2 & $5 \cdot 87$ & 3 & $3 \cdot 12$ & 3 \\
\hline North-Lakhimpur & 3.90 & 3 & 0.32 & 2 & 1.04 & 2 & 5.83 & 3 \\
\hline Dibrugarh & $9 \cdot 76^{*}$ & 3 & 1.68 & 3 & $4 \cdot 10$ & 3 & $5 \cdot 68$ & 4 \\
\hline $\begin{array}{l}\text { Normalised for } \\
\text { all the stations }\end{array}$ & 4.04 & 3 & $0-67$ & 2 & $2 \cdot 10$ & 4 & 1.86 & 3 \\
\hline
\end{tabular}

N. B.: d.f. $=$ degrees of freedom, ${ }^{*}=$ Significant at $5 \%$ level, ${ }^{* *}=$ Significant at $1 \%$ level. 
The observed and the expected frequencies of dry and wet spells for the station Tezpur are presented in table $4 \mathrm{a}$ as an example. For different series of pre-monsoon and monsoon rainfall, $\chi^{2}$-values along with the corresponding degrees of freedom are presented in table $4 \mathrm{~b}$. It is observed that for dry spell distribution during the premonsoon season, $\chi^{2}$-values are significant at $5 \%$ level for the stations Dhubri and Dibrugarh, and at $1 \%$ level for the stations Majbat and Chaparmukh. During monsoon season, dry spells at Tezpur and Majbat, and wet spells at Gauhati give significant $\chi^{2}$-values at $5 \%$ level. Thus, it seems that the frequency distribution of dry spells at Dhubri, Majbat, Chaparmukh and Dibrugarh during pre-monsoon season, and at Tezpur and Majbat during monsoon season; and wet spells at Gauhati during monsoon period does not show good fit of the geometric distribution model. However, at majority of the stations, the frequency distribution of dry and wet spells during premonsoon and monsoon periods follows the geometric distribution model.

\subsection{Cumulative frequency distribution of dry and wet spells}

Probabilities of cumulative frequencies of dry and wet spells having different lengths of run are calculated for pre-monsoon and monsoon periods using equation (6), where the cumulative probability will represent the probability distribution of the cumulative frequency. The normalised or mean curves of all the stations of the probability of cumulative frequency are shown in figure 1.

Dry spell curves show that only about $50 \%$ of the total spells have duration $<3$ days during pre-monsoon and $<2$ days during monsoon period. Ninety five per cent of the dry spells during pre-monsoon and monsoon seasons have duration $<12$ days and $<6$ days respectively. Thus, only $5 \%$ of the spells have higher durations. It is also observed that the dry spells during monsoon are of shorter duration than that of the premonsoon period.

As compared to dry spells, wet spells have shorter duration for both pre-monsoon and monsoon seasons. Wet spells having duration $<2$ days contribute about $70 \%$ and about $60 \%$ of the total wet spells occurred during pre-monsoon and monsoon season

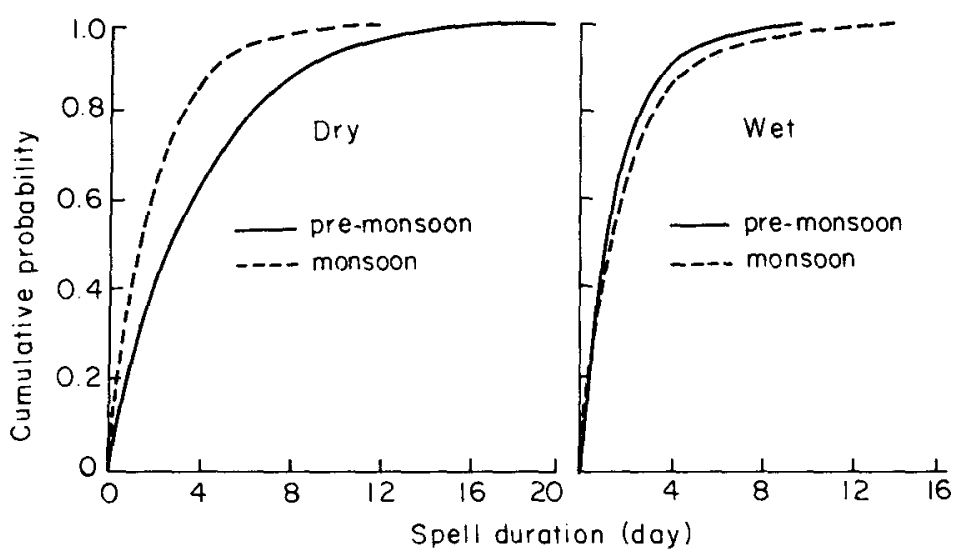

Figure 1. Normalised curves of the cumulative frequency distribution of dry and wet spells. 
respectively. Only $5 \%$ of the total wet spells have duration $>5$ days during premonsoon and $>6$ days during monsoon season.

\subsection{Expected length of weather cycle}

A weather cycle may be defined as a wet (or dry) spell followed by a dry (or wet) spell, that is, the time required by a particular type of weather to regain its original state. The expected average lengths of dry and wet spells, and hence the expected length of weather cycle for all the stations are calculated using equations (7) and (8). The results are given in table 5.

The expected lengths of a dry spell, wet spell and weather cycle are different at different stations depending upon the location of the stations. Chaparmukh shows the maximum length of dry spell during both pre-monsoon and monsoon seasons. Minimum length of dry spell for the two seasons is observed at Dibrugarh and Gauhati respectively. The expected length of a wet spell has the maximum and minimum length at Gauhati and Tangla for pre-monsoon season, while for the monsoon season the two extreme values are observed at North Lakhimpur and Lumding respectively. The expected length of a weather cycle for pre-monsoon and monsoon seasons is maximum at Chaparmukh and North Lakhimpur, and minimum at Dibrugarh and Lumding.

\subsection{Return period of dry spells}

Probable return periods of dry spells having different lengths for all the stations are calculated using Weiss's (1964) formula,

$$
T_{d}=P_{0}+P_{1} / N P_{0} P_{1}\left(1-P_{0}\right)^{i},
$$

Table 5. Expected length of dry spells, wet spells and weather cycle at various stations.

\begin{tabular}{|c|c|c|c|c|c|c|}
\hline \multirow[b]{3}{*}{ Station } & \multicolumn{3}{|c|}{ Pre-monsoon } & \multicolumn{3}{|c|}{ Monsoon } \\
\hline & \multicolumn{2}{|c|}{$\begin{array}{l}\text { Expected length of } \\
\text { spells in days }\end{array}$} & \multirow{2}{*}{$\begin{array}{l}\text { Expected } \\
\text { length of } \\
\text { weather } \\
\text { cycle in } \\
\text { days }\end{array}$} & \multicolumn{2}{|c|}{$\begin{array}{l}\text { Expected length } \\
\text { of spells in days }\end{array}$} & \multirow{2}{*}{$\begin{array}{l}\text { Expected } \\
\text { length of } \\
\text { weather } \\
\text { cycle in } \\
\text { days }\end{array}$} \\
\hline & Dry & Wet & & Dry & Wet & \\
\hline Dhubri & $5 \cdot 7$ & $2 \cdot 0$ & $7 \cdot 7$ & $2 \cdot 6$ & $2 \cdot 8$ & $5 \cdot 4$ \\
\hline Gauhati & $4 \cdot 1$ & $2 \cdot 8$ & 6.9 & $2 \cdot 2$ & $4 \cdot 1$ & $6 \cdot 3$ \\
\hline Tangla & $5 \cdot 2$ & $1 \cdot 5$ & $6 \cdot 7$ & $2 \cdot 7$ & $2 \cdot 1$ & $4 \cdot 8$ \\
\hline Tezpur & 4.8 & 2.5 & $7 \cdot 3$ & $2 \cdot 4$ & 2.8 & $5 \cdot 2$ \\
\hline Majbat & $4 \cdot 5$ & $2 \cdot 2$ & $6 \cdot 7$ & $2 \cdot 4$ & $2 \cdot 3$ & $4 \cdot 7$ \\
\hline Lumding & $4 \cdot 0$ & $1 \cdot 7$ & $5 \cdot 7$ & $2 \cdot 6$ & 1.8 & $4 \cdot 4$ \\
\hline Chaparmukh & $6 \cdot 2$ & $2 \cdot 5$ & $8 \cdot 7$ & $3 \cdot 0$ & $2 \cdot 2$ & $5 \cdot 2$ \\
\hline Hafiong & 4.8 & $2 \cdot 0$ & 6.8 & $2 \cdot 8$ & $2 \cdot 0$ & 4.8 \\
\hline North-Lakhimpur & $3 \cdot 5$ & $2 \cdot 7$ & $6 \cdot 2$ & $2 \cdot 3$ & $4 \cdot 4$ & $6 \cdot 7$ \\
\hline Dibrugarh & 3.0 & $2 \cdot 4$ & $5 \cdot 4$ & $2 \cdot 4$ & $4 \cdot 2$ & 6.6 \\
\hline Mean & $4 \cdot 6$ & $2 \cdot 2$ & 6.8 & $2 \cdot 5$ & $2 \cdot 9$ & $5 \cdot 4$ \\
\hline
\end{tabular}


where $T_{d}=$ return period in years, $N=$ number of days in the series or study period, $i=$ length of dry spell, and $P_{0}, P_{1}$ are conditional probabilities. The results are given in table 6. It is observed that for a particular return period the length of dry spell is the maximum at Chaparmukh for both pre-monsoon and monsoon seasons. On the other hand the minimum length of dry spells for a particular return period is observed at Dibrugarh for pre-monsoon period, and at Gauhati and North Lakhimpur for monsoon. In the region as a whole, during pre-monsoon, dry spells have a duration of 10 days with return period 1 year, 13 days with return period of 2 years, 14.5 days with return period of 3 years and so on.

\section{Conclusion}

The present study shows that the daily rainfall in the Brahmaputra Valley persists and their distribution may be represented by a first-order Markov Chain model. The adequacy of the model varies from station to station and from season to season. For majority of the rainfall series, spells of dry and wet days having different length of run follow geometric distribution. Their respective cumulative frequency distributions show that about $95 \%$ of both dry and wet spells have duration $<6$ days during monsoon season. But for pre-monsoon season $95 \%$ of the dry spells have duration $<12$ days and of wet spells have duration $<5$ days. The average length of a weather cycle in the region as a whole is expected to be 6.8 days during pre-monsoon and 5.4 days during monsoon. Return period analysis of dry spells shows that for a particular return period out of all the stations, Chaparmukh shows the greatest durations of spell in both pre-monsoon and monsoon seasons. The findings have, however, not been verified on independent data.

Table 6. Probable length of dry spell at different stations for different return periods.

\begin{tabular}{|c|c|c|c|c|c|c|c|c|c|c|}
\hline \multirow[b]{4}{*}{ Station } & \multicolumn{5}{|c|}{ Pre-monsoon } & \multicolumn{5}{|c|}{ Monsoon } \\
\hline & \multicolumn{5}{|c|}{$\begin{array}{l}\text { Duration of dry spells in } \\
\text { days for the return period }\end{array}$} & \multicolumn{5}{|c|}{$\begin{array}{l}\text { Duration of dry spells in } \\
\text { days for the return period }\end{array}$} \\
\hline & \multicolumn{5}{|c|}{ Years } & \multicolumn{5}{|c|}{ Years } \\
\hline & 1 & 2 & 3 & 5 & 10 & 1 & 2 & 3 & 5 & 10 \\
\hline Dhubri & 13 & 17 & 19 & 21 & 25 & 6 & 8 & 9 & 10 & 11 \\
\hline Gauhati & 9 & 12 & 13 & 15 & 17 & 5 & 6 & 7 & 8 & 9 \\
\hline Tangla & 12 & 16 & 18 & 20 & 23 & 7 & 8 & 9 & 10 & 12 \\
\hline Tezpur & 11 & 14 & 16 & 18 & 21 & 6 & 7 & 8 & 9 & 10 \\
\hline Majbat & 11 & 13 & 15 & 17 & 20 & 6 & 7 & 8 & 9 & 10 \\
\hline Lumding & 10 & 12 & 14 & 15 & 18 & 7 & 8 & 9 & 10 & 12 \\
\hline Chaparmukh & 13 & 17 & 20 & 23 & 26 & 8 & 10 & 11 & 12 & 14 \\
\hline Haflong & 11 & 14 & 16 & 18 & 21 & 7 & 9 & 10 & 11 & 13 \\
\hline North-Lakhimpur & 8 & 10 & 11 & 13 & 15 & 5 & 6 & 7 & 8 & 9 \\
\hline Dibrugarh & 7 & 9 & 10 & 11 & 13 & 5 & 7 & 7 & 8 & 10 \\
\hline Mean & 10.2 & $12 \cdot 9$ & $14 \cdot 5$ & $16 \cdot 4$ & $19 \cdot 1$ & $6 \cdot 3$ & $7 \cdot 7$ & $8 \cdot 5$ & $9 \cdot 5$ & $10 \cdot 9$ \\
\hline
\end{tabular}




\section{References}

Anderson T W and Goodman L A 1957 Ann. Math. Stat. 2889

Bhargava P N et al 1977 Monogr. Inst. Agric. Res. Stat. New Delhi p. 76

Caskey J E Jr 1963 Mon. Wea. Rev. 91298

Feyerherm A M and Bark L D 1967 J. Appl. Meteor. 6770

Fitzpatrick E A and Krishnan A 1967 Arch. Met. Geophys. Niokl. B15 242

Gabriel K R and Neumann J 1962 Q. J. R. Meteor. Soc. 8890

Medhi J 1976 Indian J. Meteor. Hydrol. Geophys. 27431

Sundararaj N and Ramachandra S 1975 Indian J. Meteor. Hydrol. Geophys. 26221

Victor U S and Sastry P S N 1979 Mausam 30479

Watterson G A and Legg M P C 1967 Aust. Meteor. Mag. 151

Weiss L L 1964 Mon. Wea. Rev. 92169 